EJTD

38,3

162

Received 3 July 2013

Revised 29 September 2013

Accepted 2 October 2013

\section{Competence development and performance among Swedish micro firms}

\author{
Darush Yazdanfar \\ Department of Business Administration, Mid Sweden University, \\ Östersund, Sweden \\ Saeid Abbasian \\ Department of Tourism Studies and Geography, Mid Sweden University, \\ Östersund, Sweden, and \\ Carina Hellgren \\ Division of Education and Research Administration, Mälardalen University, \\ Västerås, Sweden
}

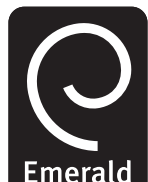

European Journal of Training and Development

Vol. 38 No. 3, 2014

pp. $162-179$

(c) Emerald Group Publishing Limited 2046-9012

DOI 10.1108/EJTD-10-2013-0106

\begin{abstract}
Purpose - This study examines the association between performance and competence development among Swedish micro firms, measured as number of hours per person a company allocates annually to competence development.

Design/methodology/approach - A panel dataset consisting of around 395 firms will be analyzed using seemingly unrelated regression-model (SUR-model) for relationships between the hours allocated to competence development and various proxies for business performance, and the relationship between attending a business training program and various proxies for business performance.

Findings - The empirical results are mixed showing a positive association between owners' attendance on a business training program and company performance merely with regard to four performance variables: better job satisfaction within a company, increased number of employees, organizational improvements and increased exports. However, the findings provide no evidence to suggest that there is a link between competence development and other performance variables.

Practical implications - The present study provides a better understanding of the relationship between company performance and competence development. An investment in entrepreneur training and education could ensure the improvement of the performance of micro firms. This implication is especially relevant to firms in such industries as the service sectors, which are highly competitive.

Originality/value - This study is based on a unique sample including many relevant variables, compared to previous researches. To the authors' best knowledge, this study is the one of the first empirical investigations focusing on this issue in the Swedish context.
\end{abstract}

Keywords Performance, Business training, Micro firms, SUR model, Sweden

Paper type Research paper

\section{Introduction}

It is believed that micro firms play an important role in national economies in terms of jobs and growth (Reynolds, 2012). Despite structural changes in the Swedish economy during recent decades (Schön, 2010), Sweden is still recognized as an export nation, in industry as well as in service exports. Because of the changes, it is important to find new 
ways to strengthen or maintain Sweden's capacity for export and to make the country more competitive. And it is especially important to increase the export capacity of small firms. One important issue to consider is how to help these micro firms achieve better performance, to reach this goal, since it is not only major multinational companies that create and sustain Swedish prosperity, but also small firms.

Competence development is an area that has been featured in recent research but that needs to be studied further: the role of competence development and its relationship with performance in micro firms, and more precisely how competence development of both owners and their staff can have a positive influence on performance, especially performance related to production and export. Lack of, or insufficient, competence development, may constitute a barrier for better performance.

In this study we make an attempt to show how competence development by micro firm owners and their staff may be related to the business performance of Swedish micro firms. This is a way to better understand how micro firms in Sweden can strengthen their performance through competence development, and eliminate constraints that might constitute barriers to better production and export. Hopefully it could also motivate new businesses and allow newcomers to follow the same path.

The previous literature suggests that a business' performance can be defined, evaluated and measured in various ways (see for example reviews by Haber and Reichel, 2005; Soriano and Castrogiovanni, 2012). Indicators of business performance include: attainment of goals and resources/means, size of business in term of revenue and number of staff, profitability, flexibility of organizational structure, growth in sales and market share, customer satisfaction, success and survival (Haber and Reichel, 2005; Soriano and Castrogiovanni, 2012). Two criteria in this connection are profitability (Murphy et al., 1996) and productivity (Maroto and Rubalcaba, 2008). Regardless of different theoretical approaches to performance, it can be measured either objectively (i.e. mostly by financial data) or subjectively (i.e. more wide and flexible for multi-industry comparison such as growth in sale and market share) (Haber and Reichel, 2005). Performance can also be measured both for short and long terms in all circumstances (ibid, see also Haber and Reichel, 2005, 2007).

\section{Theoretical framework and previous research}

Competence development has been mostly studied in large or medium-sized firms. Earlier research has been mainly concerned with the causal relationship between human recourse management (HRM) or human resource development (HRD) and organizational performance (e.g. Fleetwood and Hesketh, 2008; Hesketh and Fleetwood, 2006). Other studies have measured firm performance by a number of subjective or objective indicators but there is a doubt if such HRD results in higher company performance (Guest et al., 2003; see also Hesketh and Fleetwood, 2006). Some also has scrutinized earlier research due to neglecting the important role of managers in HRD practice and performance of companies (e.g. Purcell and Hutchinson, 2007) and have tried to consider the influence of such indicators on the HRD practice of companies like good leadership and employee satisfaction.

However, a number of other previous empirical studies show a positive attitude towards vocational learning especially in small businesses. For instance several Dutch research have shown the importance of long-life learning, especially workplace learning, for the competence development of entrepreneurs in agri-food sector and also
Competence development

163 
EJTD

38,3

164 for the whole country (Lans et al., 2004, 2010; Mulder et al., 2007). In two studies by Lans et al. (2008a, b) they not only showed the importance of entrepreneurship training and education programs for the competence development of small business owners, but also the important role that working environment plays in such learning process.

Business performance, as Man et al. (2008) show in their literature review, can be affected by many factors; individual factors such as gender, ethnicity, age, psychological and behavioral characteristics, social and human capital, and contextual, organizational and strategic factors.

Other authors suggest that a micro firm's performance can be studied in the light of a resource-based theory, with special attention to human capital resources of the firm's owner/founder and their staff (Segal et al., 2010, 2007). Bergmann-Lichtenstein and Brush (2001) consider entrepreneurship to be a process of resource accumulation and used opportunities for the business. Other authors (e.g. Barney, 1991; Haber and Reichel, 2007) describe the entrepreneurial process and resource accumulation by treating human capital resources as one of the three most significant bases of a firm's performance, alongside physical capital resources and organizational capital resources. Nevertheless, Segal et al. $(2010,2007)$ consider the firm owner's human capital might be the most significant component of a micro firm's success.

Numerous authors believe that an owner's formal education is the most fundamental human capital resource, often described as the main factor in the performance and success of a business (see, e.g. Cooper and Gimeno-Gascon, 1992; Becker, 1993; Hitt et al., 2001; Jo and Lee, 1996; Mengistae, 2006; Sapienza and Grimm, 1997). Previous studies have also shown that the education of the staff has a significant impact on business performance (Chow, 2006). Parker and van Praag (2006) show, for example, that the higher educational level of owners, the more positive the impact on their financing (reduces capital constraints), and the more improvement in a firm's performance. Other authors (e.g. Dahl and Reichstein, 2007; Georgellis et al., 2007) however suggest that their higher education has no significant impact on business survival.

Nevertheless, good formal education on its own is not enough to guarantee a firm's good performance. An entrepreneur and their staff also need human resource development, i.e. other competencies or competence development as well as the formal education to achieve better performance for the firm. The expression "competence development" is often used in the relevant literature more or less synonymously with skill development. We have chosen to use "competence development" and subscribe to the definition given by Brown, who explains that competence development in business simply means human resource development (Brown, 1999) related to the business owner and their business. He includes all competences gained through training, and attendance on all courses that enable the owner to better deal with issues in their business, that is, everything beyond the formal education of the owner and staff. It may also be partly interpreted as per Bird's (1995) definition of formally learned entrepreneurial competence/competencies. Human resource development can also be defined as human resource management and management development that is of significance for both small and large firms and their performance at national and international level (Mabey, 2008; see also Mabey and Gooderham, 2005; Mabey and Ramirez, 2005). Moreover, the owner's managerial background and experience, or lack of, is considered a contributing factor to the success or failure of a small firm (Steiner 
and Solem, 1988). Managerial competencies (competence associated with effective management and leadership - defined by Martin and Staines, 1994) are also confirmed to play an important role in the development of small and medium size enterprises (Chye et al., 2010; Bird, 1993). Studies into "lifestyle business" ventures in the tourism industry (Lerner and Haber, 2001; Haber and Reichel, 2007) also confirm that an entrepreneur's human capital, particularly their managerial competence, is the major contributing factor to performance success. Enz (2004) and Camillo et al. (2008), for example, consider effective training programs and the competence of employees as a success or failure factor, whilst Sharlit (1990) emphasizes the owner's competence.

A European study (Millan et al., 2012) showed that owners' formal education and previous work experience in the labour market has positive effects on business survival, while entering the business world from unemployment has the opposite effect on survival. This means, in other words, that gaining the relevant competence prior to start up is much better than starting without it. Soriano and Castrogiovanni (2012) in their study into micro firms in the EU found positive impacts of education, experience and inner advisors on the performance of micro firms in terms of profitability and productivity.

A common definition of competence development in entrepreneurship is called "entrepreneurship education" (Mwasalwiba, 2010). People can attend such education without necessarily starting or running a business, and even those who are not running a business can attend such courses to learn more about it prior to launching their own, as is common in Sweden. Some typical subjects in such courses are financing, marketing, business planning, risk and rationality, managerial growth, SME management, and opportunity discovery (Mwasalwiba, 2010).

Other authors discuss it in terms of entrepreneurial competencies. Man et al. (2008) found a relationship between an entrepreneur's entrepreneurial competencies (human and strategic competencies) and the long term performance of small and medium size enterprises in Hong Kong. Entrepreneurial competencies are believed to play an important role not only in the performance and competitiveness of a firm (Man et al., 2002), but also in its growth and success (Colombo and Grilli, 2005). A study in Belgium (Seghers et al., 2012) shows, for example, that entrepreneurs with business education, or experience with accountancy or finance, have a broader knowledge of financing alternatives than their counterparts who lack such competencies. It is also included in their specific human capital (Dimov and Shepherd, 2005) in comparison to their generic human capital, i.e. their general knowledge based on formal education and experience (Seghers et al., 2012).

According to Kock et al. (2006), and Kock and Ellström (2011), the competence development of staff consists of various activities and individual learning processes aimed at improving an employee's competence. They also classify competence development into four categories: formal, informal, internal and external. Formal competence development means all planned/organized learning activities that are included in working hours and mainly financed by the employer, while informal competence development is unplanned spontaneous learning through participation in various work activities. Finally planned training programs are managed by either internal or external courses (ibid).

From several previous studies (e.g. Spalter-Roth et al., 1994; Sanders, 2002; Klein et al., 2003) it is clear that such training programs are appreciated by the micro firm owners and have a positive impact on their lives, and, in particular, on their business
Competence development

165 
EJTD

38,3

166 activities. A relatively recent study in the USA on women entrepreneurs attending entrepreneurship training (Bauer, 2011) indicated that these courses had a positive impact on an owner's individual development and their business in terms of growth prospects. For example they learned how to structure their plans/ideas independently and how to deal with the advertisement and marketing of their businesses. They also gained more confidence in aspects such as financing, day-to-day operation and accounting. These courses were considered by the women to be a key factor in their later business success.

There are, on one hand, critical studies emphasizing that competence development or better skill formation is not enough for the economic performance of a micro firm (see, e.g. Crouch et al., 1999; Rainbird, 2000), and on the other hand, authors who stress other important factors such as government, labor market regulations, education and training systems, and financing (see for example Panagiotakopoulos, 2011, p. 113). Nonetheless Panagiotakopoulos concludes that training activities for small business owners and their staff could be created through owners' and employees' willingness, a firm's competitive strategy and its work organization (Panagiotakopoulos, 2011). O'Connor (2013) also concludes that entrepreneurship education has a vague relationship with successful economic outcomes. Success in performance might not always be explained by factors such as education, training, or other relevant competencies. Other authors, such as Butler et al. (2003), focus on network and information resources which they believe have more impact on a firm's performance.

\section{Selection of variables, hypothesis}

\subsection{Selection of variables}

3.1.1 The independent variable. Based on Kock et al. (2006) and Kock and Ellström (2011) this paper focuses on external formal competence development, i.e. external courses mainly financed by employers. The independent variable in this study is competence development measured by the number of hours a company allocates annually per person to competence development.

3.1.2 The dependent variable. As mentioned earlier dependent variable performance can be measured in several ways. A number of studies have used profitability (Bosma et al., 2000), business growth (O'Gorman, 2001) or survival rates (Bruederl et al., 1992) as proxies of performance. Others have used employment growth (Cooper et al., 1997), or product innovativeness (Cooper, 1979) and market share (Chandler and Hanks, 1993) as measurements of performance.

Following the theoretical frameworks and previous literature, 13 relevant variables were selected as preliminary dependent variables. Before starting the multivariate analysis, a significance test was carried out to examine which variables were statistically significantly linked to the independent variable "competence development". Respondent perceptions of the impact of competence development on their performance were collected using a ratio scale of 0 to $5(0=$ not enough; and $5=$ enough). Based on the results of correlation analysis, statistically significant relationships were found between competence development programs and four dependent variables: competence development and an improved well-being of the company, the propensity to hire more people, organizational improvement and increased exports. Only these variables were subsequently used in the SUR model (seemingly unrelated regression). 
This study is based on a unique, firm-level panel database gathered through a survey in October-November 2012 by the Swedish Small Business Forum. The survey was done using a questionnaire consisting of 60 multiple choice questions and during a business training program organized by Företagsakademin (Eng. The Business Academy) in Stockholm. The training program was held between 1 January 2011 and 30 June 2013 and consisted of several courses offered by training companies. The courses were tailored for micro firms which had less than ten employees and had development and training plans. The firms also had to be running at least for one year and had to have offices in Stockholm County. All the respondents of the questionnaire had participated in the same competence development program and were either the business owner, the CEO or both. The response rate for the questionnaire was 44 percent at the company level, 530 participants or 395 companies, which can be considered a quite high response rate (Baruch and Holtom, 2008).

\subsection{Hypothesis}

In light of previous studies, the following hypothesis has been formulated. Unlike the majority of previous studies, the current research is based on a larger number of dependent variables and uses a larger sample than most of the previous studies. Because of the cross-sectional design of the study, causal relationship cannot be studied:

H1. The performance of firms is expected to be positively related to the owners and CEOs attending business training programs.

\section{Empirical results}

\subsection{Descriptive statistics of sample}

The descriptive statistics of the main firm and owner characteristics in the dataset are displayed in Table I. Around 62 percent of the business owners were female, and of those taking part in the survey, roughly 85 percent were born in Sweden. Nearly 70 percent of respondents reported some college education, a bachelor's degree, or more advanced training in an undergraduate or graduate setting, while 30 percent of respondents held a primary and secondary school degree. The age of respondents was on average 38.7 years, which was categorized into four groups. The highest concentration of respondents (54 percent) was found in the 31 to 50 age category.

Concerning industrial affiliation, around 80.5 percent of all firms are active in the services sector, 5.5 percent in the manufacturing sector and remaining 11.3 percent as retail firms. The firms were in general young micro firms with an average age of 2.6 years and had on average 3 employees.

\subsection{Descriptive statistics of independent and dependent variables}

In order to measure the relationship between joining a competence developing project on performance, the respondents were asked to express their opinions about links between attainment in competence projects and performance. A total of 13 different proxies were constructed for performance on a six-point scale (where the lowest score $=0$, and the highest score $=5$ ). The dependent variables in the model assume a value of six if the respondent did observe a very strong effect of competence development on performance variables. Otherwise, the value for a firm which has not used external capital assumes the value 0 .
Competence development

167 


\begin{tabular}{|c|c|c|c|c|c|}
\hline \multirow{3}{*}{$\begin{array}{l}\text { EJTD } \\
38,3\end{array}$} & \\
\hline & Question and answer options & Frequency & $\%$ & Valid \% & Cumulative $\%$ \\
\hline & $\begin{array}{l}\text { Gender } \\
\text { Female } \\
\text { Male }\end{array}$ & $\begin{array}{l}331 \\
200\end{array}$ & $\begin{array}{l}62.30 \\
37.70\end{array}$ & $\begin{array}{l}62.30 \\
37.70\end{array}$ & $\begin{array}{r}62.30 \\
100.00\end{array}$ \\
\hline \multirow[t]{3}{*}{168} & $\begin{array}{l}\text { Ethnicity } \\
\text { Native }\end{array}$ & 450 & 84.70 & 88.00 & 88.00 \\
\hline & $\begin{array}{l}\text { Immigrant } \\
\text { No answer }\end{array}$ & $\begin{array}{r}62 \\
19\end{array}$ & $\begin{array}{r}11.70 \\
3.60\end{array}$ & $\begin{array}{r}12.00 \\
3.60\end{array}$ & 1.00 \\
\hline & $\begin{array}{l}\text { Education } \\
\text { Elementary school or equivalent } \\
\text { Secondary school } \\
\text { University education less than } 3 \text { years } \\
\text { University education more than } 3 \text { years } \\
\text { No answer }\end{array}$ & $\begin{array}{r}14 \\
129 \\
117 \\
257 \\
14\end{array}$ & $\begin{array}{r}2.60 \\
24.30 \\
22.00 \\
48.40 \\
2.60\end{array}$ & $\begin{array}{r}3.00 \\
25.00 \\
23.00 \\
50.00 \\
2.60\end{array}$ & $\begin{array}{r}3.00 \\
28.00 \\
50.00 \\
1.00\end{array}$ \\
\hline $\begin{array}{l}\text { Table I. } \\
\text { Summary of descriptive } \\
\text { statistics for } \\
\text { characteristics of } \\
\text { respondents }\end{array}$ & $\begin{array}{l}\text { Age } \\
<30 \text { years } \\
31-50 \text { years } \\
51-60 \text { years } \\
61>\text { years } \\
\text { No answer }\end{array}$ & $\begin{array}{r}45 \\
290 \\
131 \\
46 \\
19\end{array}$ & $\begin{array}{r}8.50 \\
54.60 \\
24.70 \\
8.70 \\
3.60\end{array}$ & $\begin{array}{r}9.00 \\
57.00 \\
26.00 \\
9.00 \\
3.60\end{array}$ & $\begin{array}{r}9.00 \\
65.00 \\
91.00 \\
100\end{array}$ \\
\hline
\end{tabular}

Table II summarizes the descriptive statistics for the independent and dependent variables, including mean, standard deviation and number of observations. As the last column of the table shows, the corresponding value of mean/standard deviation ratio of five dependent variables (better job satisfaction in company, increased exports, increased sales, organizational improvements, hiring more employees) are highest. Thus these variables have been regarded by respondents as the variables with the strongest links to attainment in a competence project.

\subsection{Correlation analysis of hours allocated to competence development and various proxies for business performance}

Table III presents the results of correlation analysis between variable F33 and different kind of proxies for performance. From the table, it can be concluded that there is a positive and significant correlation between variable F33, namely the annual hours spent by the company per/person, on competence development and improved well-being of the company, to hire more people, organizational improvements and increased exports. Furthermore, the last three variables are also positive and have statistically significant correlations with increased sales, increased revenue, and increased profitability, as well as with enhanced business networks. This implies that the hours per year per person allocated to competence development have an indirect link with increased sales, increased revenue, increased profitability and enhanced business networks.

\subsection{Association between attending a business training program and various proxies for business performance \\ To examine the hypothesis formulated previously, a correlation analysis was carried out to identify the performance variables with a link to businesses attending a business}




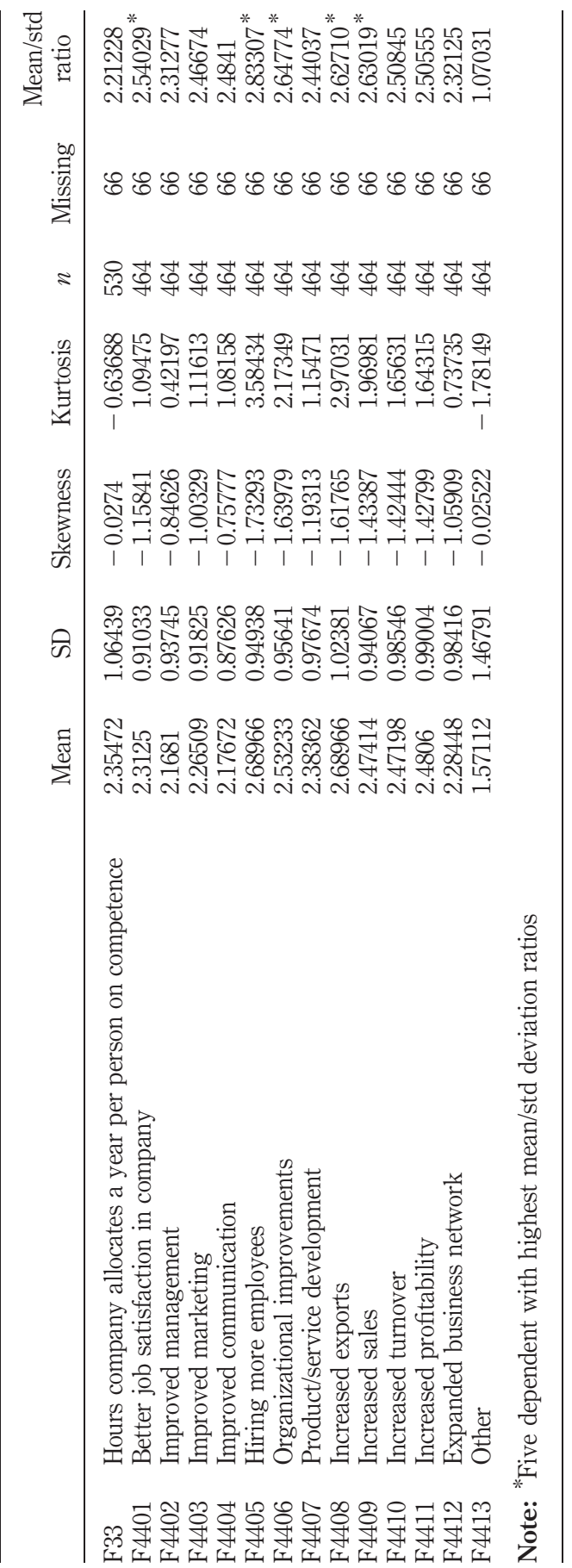

Competence development

169

Table II.

Mean, standard deviation, and number of independent and dependent variables 
EJTD

38,3

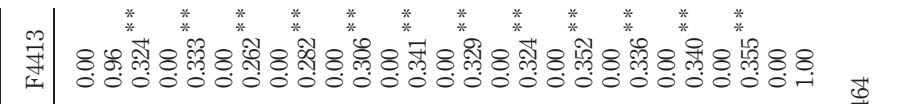

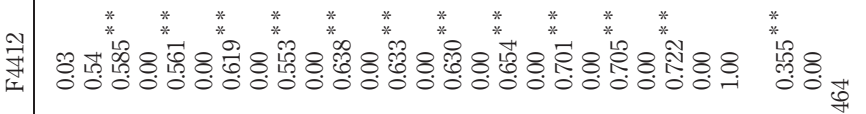

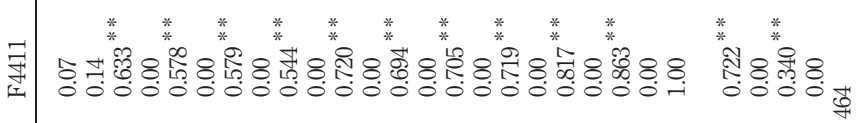

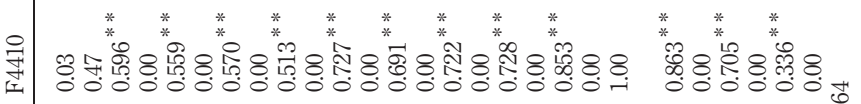

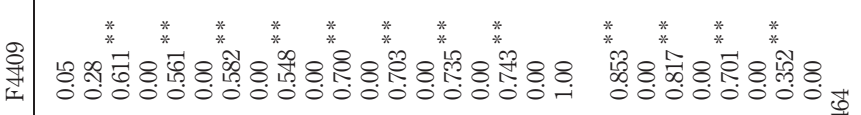

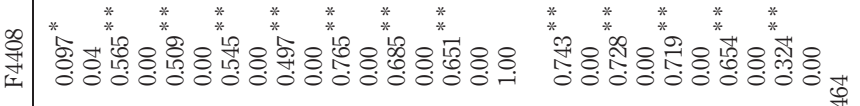

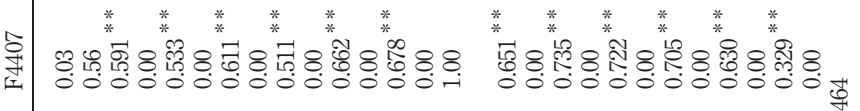

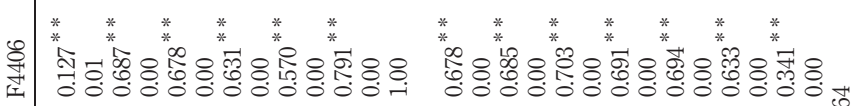

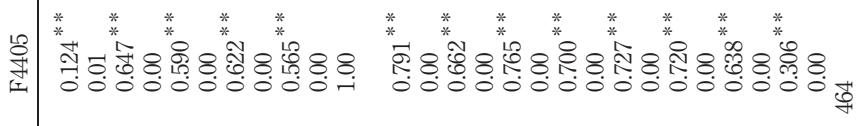

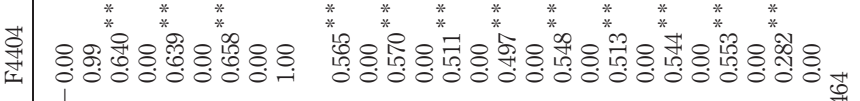

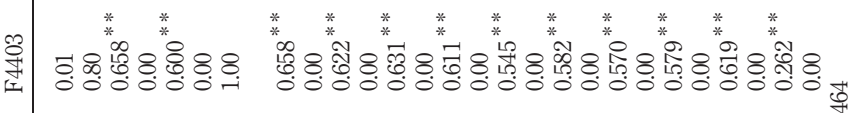

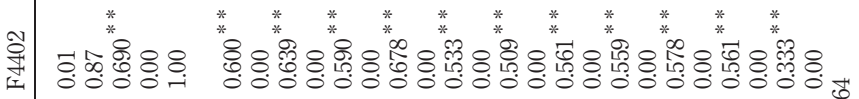

Table III.

Result of correlation analysis of variables F33 and F4401-F4413

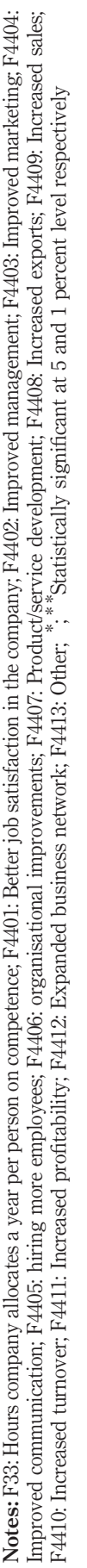


training program. Subsequently, a seemingly unrelated regression (SUR) was implemented to examine the relationship between attending a business training program and performance variables classified by correlation analysis as relevant dependent variables. The reason for using seemingly unrelated regression (SUR) model as the main method in this study was to overcome risk of correlation between error terms and the equations (heteroscedasticity) (Zellner and Theil, 1962).

Thus, the independent variable in the model is attending a business training program which has been organized by the government. The dependent variables in the model are performance in four terms: better job satisfaction in the company, hiring more employees, organizational improvements, and increased exports. Thus, an SUR was performed to analysis the relationship between business training and the dependent variables performance. The underlining equation in SUR is in accordance with the following formula:

Performance in four terms is included in models according to following equations:

(1) First SUR-model: dependent variable: better job satisfaction in the company, $\mathrm{Y}=\alpha_{0}+\beta_{1}(\mathrm{X} 1)+\varepsilon$.

(2) Second SUR-model, dependent variable: hire hiring more employees $=\alpha_{0}+\beta_{1}(\mathrm{X} 1)+\varepsilon$.

(3) Third SUR-model, dependent variable: organizational improvements $=\alpha_{0}+\beta_{1}(\mathrm{X} 1)+\varepsilon$.

(4) Fourth-model, dependent variable: increased exports $=\alpha_{0}+\beta_{1}(\mathrm{X} 1)+\varepsilon$.

Where:

- $\alpha_{0}$ : Constant;

- $\beta_{1}=$ attendance of a business training program.

- F33: measured in term of number of hours per person a company allocates annually to competence development.

- $\varepsilon=$ Error term.

The outcome of the SUR models for the relationships between the explanatory variable, attendance of a business training program, and the four dependent variables; better job satisfaction in the company, hiring more employees, organizational improvements, and increased exports, are presented below. The results present the coefficient estimation and the standard error and p-value for testing the null hypothesis that the coefficient of each covariate is equal to zero.

Table IV shows the results of the first SUR model, which confirms that the independent variable F33 had a positive and statistically significant relationship with the dependent variable F4401 (Better job satisfaction in the company). R Square measures the explanatory power of the model showing that the independent variable explains 0.010 of change in the dependent variable. The Durbin-Watson statistics, with a value around 2 , confirm the overall best fit and validity of the model. In addition, the diagnostic tests including variance inflation factor $(\mathrm{VIF}=1.2)$ and the Breusch-Pagan/Cook-Weisberg tests $(\mathrm{P}=0.0089)$ point to the appropriate specification.
Competence development 
EJTD

38,3

172

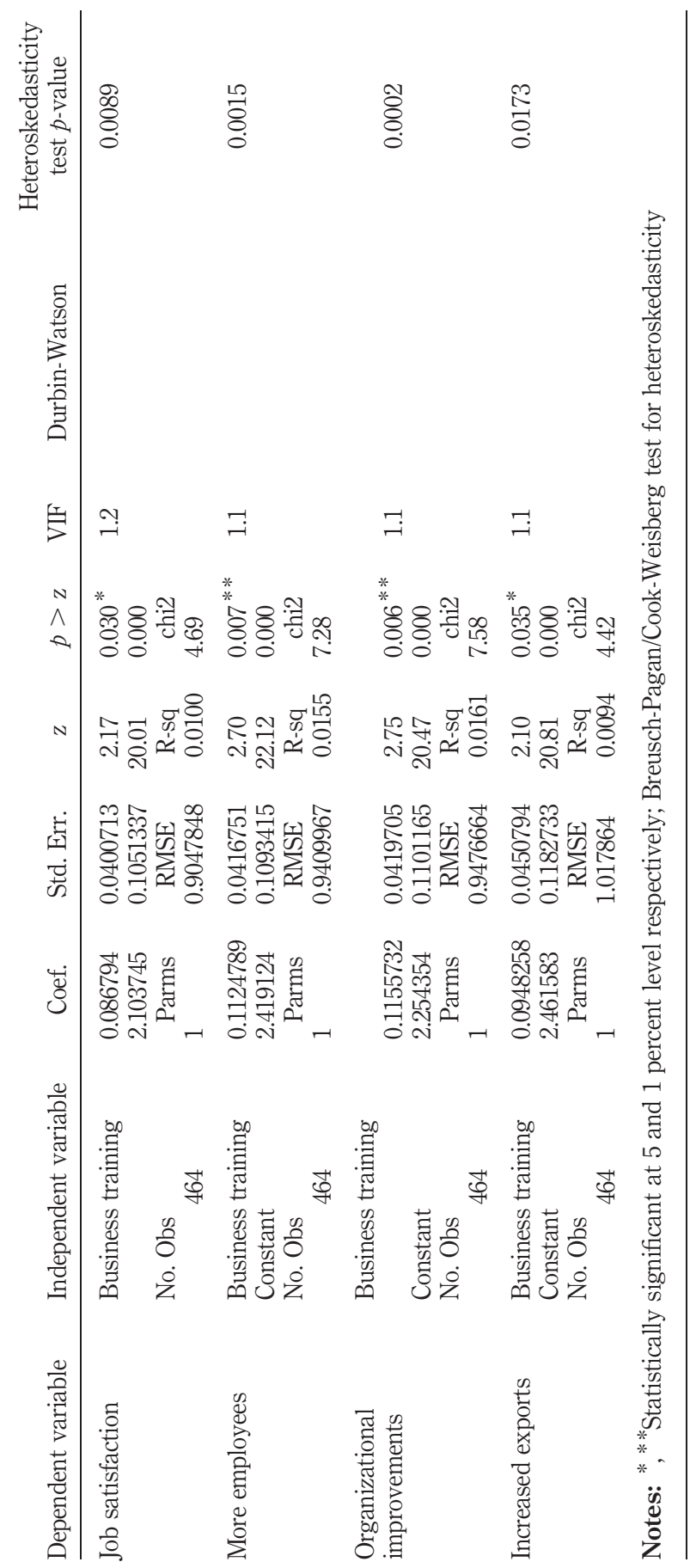

Table IV.

The results of SUR models 
$\mathrm{n}$ Table IV, the coefficient of the second model is positive and statistically significant at the 5 percent level, indicating that attendance on a business training program was positively related with an increased hiring of employees. The independent variable in this case explains about 0.015 percent of the change in the dependent variable. The diagnostic tests, Durbin-Watson, VIF $(\mathrm{VIF}=1.1)$ and the Breusch-Pagan/CookWeisberg $(\mathrm{P}=0.0015)$, all confirm the statistical significance of the results.

Furthermore, the results of the third model evidently demonstrate that there is an association between the independent variable and organizational improvements. The respondents confirm the positive relationship between business training and organizational changes. The validity tests of the third SUR model, including Durbin-Watson, VIF (VIF = 1.1) and the Breusch-Pagan/Cook-Weisberg $(\mathrm{P}=0.0002)$ confirm the robustness of the results. To investigate further, logistic regression analyses were carried out.

That the statistically significant coefficient of the fourth model is positive implies that business training is positively related also to increased exports. The results obtained in the multicollinearity statistics, or variance inflation factor (VIF), where the VIFs of all independent variables are close to 1 confirm that there is generally no reason to be concerned about multi-collinearity.

These results support the hypothesis formulated, with regards to four of the proxy performance variables. However, the results provide no support that other proxy performance variables are related to the independent variable business training.

Comparing the predictors of four SUR models reported in Table IV, it can be confirmed that both coefficient and explanatory power of the third model in terms of $\mathrm{R}$-sq are larger than those of other models.

In summary, the empirical findings in agreement with hypothesis $H 1$ demonstrate that business training is an important variable in explaining change in performance in terms of better job satisfaction in the company, hiring more employees, organizational improvements, and increased exports, and as a result leads to higher performance in the business. We have not found any previous research that supports our result of positive impact on job satisfaction. Nevertheless the rest of our results are supported by studies carried out by, among others, Haber and Reichel (2005) stressing better performance through a competitive values approach with the focus on organizational flexibility; authors focusing on goal approach in terms of the number of employees (Orser et al., 2000; Mohr and Spekman, 1994), and authors emphasizing assessing performance approaches in term of market share or growth in market share (Bouchikhi, 1993; Tsai et al., 1991; McDougall et al., 1992).

\section{Conclusions, limitations and implication}

Many studies have been conducted to investigate the relationship between the competence development programs and the competitive advantage of companies. In most of these studies, however, the center of interest has been only on large or middle size firms and how their competitive advantage may be influenced by such programs. In this study, however, we try to examine the influence of such programs on the business performance of micro firms. Therefore it aims to fill a gap in the current empirical knowledge in this area and provide some practical implications for micro firm owners/mangers, public policy makers, and training suppliers.
Competence development

173 
EJTD

38,3

174
The study is based on a database acquired from a sample of 395 Swedish young micro firms. It investigates the relationship between the training programs provided for the owners/managers of these firms and thirteen business performance variables. Out of the 13 performance variables, this study has found competence development programs to be positively related to four performance variables of micro firms. These four performance variables are better job satisfaction, organizational improvements, employee increase and export increase. The competence development program also has been measured in terms of the number of hours in a year allocated by the owner/manager of a micro firm to business training programs.

One of the findings of this study that distinguishes it from similar previous studies can be attributed to its finding regarding the influence of competence development programs on "job satisfaction" which anecdotally has been assumed to be more or less related to business success. The result of this study shows a statistically significant relationship between the number of hours allocated to competence development programs and "job satisfaction". Since job satisfaction has been shown to be related to various health outcomes as well as to the increased performance of employees (Böckerman and Ilmakunnas, 2012), it was not far fetched to assume that there might also be an association with competence development.

The other findings of this study are in accordance with most of the previous research findings. That is, the relationship between competence development programs and performance variables such as organizational flexibility (e.g. Haber and Reichel, 2005), the number of employees (e.g. Orser et al., 2000; Mohr and Spekman, 1994), and growth in market share (e.g. Bouchikhi, 1993; Tsai et al., 1991; McDougall et al., 1992).

This study is also subjected to some limitations mainly associated with the sample selection. First, the study is based on a database gathered from Swedish micro firms, and therefore its findings may not be generalized to all firms operating in different socio-economic contexts. Second; assessing the improvement in the business performance of a firm based on the training programs attended by its owner/manager is a complex dynamic process which might also be linked to other variables such as the personal characteristics of the owner/manager or the characteristics of the firm. However, this study has not controlled for such variables as personal characteristics (e.g. gender, ethnicity, age) or firm characteristics.

The result of this study, along with the lack of enough empirical work in this area, urge the need for more resources and attention to be devoted in futures studies to the association between business training programs and the business performance of micro firms.

\section{References}

Barney, J. (1991), "Firm resources and sustained competitive advantage", Journal of Management, Vol. 17 No. 1, pp. 99-120.

Baruch, Y. and Holtom, B. (2008), "Survey response rate levels and trends in organizational research", Human Relations, Vol. 61 No. 8, pp. 1139-1160.

Bauer, K. (2011), "Training women for success: an evaluation of entrepreneurship training programs in Vermont, USA", Journal of Entrepreneurship Education, Vol. 14, pp. 1-24.

Becker, G.S. (1993), Human Capital: A Theoretical and Empirical Analysis, with Reference to Education, The University of Chicago Press, Chicago, IL. 
Bergmann-Lichtenstein, B.M. and Brush, C.G. (2001), "How do 'resource bundles' develop and change in new ventures? A dynamic model and longitudinal exploration", Entrepreneurship Theory and Practice, Vol. 25 No. 3, pp. 37-58.

Bird, B. (1995), "Towards a theory of entrepreneurial competency", in Katz, J.A. and Brockhaus, R.H. (Eds), Advances on Entrepreneurship, Firm Emergence and Growth, Vol. 2, JAI Press, Greenwich, CT, pp. 51-72.

Bird, B. (1993), "Demographic approaches to entrepreneurship: the role of experience and background", in Katz, J.A. and Brockhaus, R.H. (Eds), Advances in Entrepreneurship, Firm Emergence, and Growth, Vol. 1, JAI Press, Greenwich, CT, pp. 11-48.

Bosma, N., van Praag, M. and de Wit, G. (2000), "Determinants of successful entrepreneurship", Research Report 0002/E, SCALES - SCientific AnaLysis of Entrepreneurship and SMEs, Netherlands Ministry of Economic Affairs, The Hague.

Bouchikhi, H. (1993), "A constructivist framework for understanding entrepreneurship performance”, Organization Studies, Vol. 14 No. 4, pp. 549-570.

Brown, P. (1999), "Globalisation and the political economy of high-skills", Journal of Education and Work, Vol. 12 No. 3, pp. 233-251.

Bruederl, J., Preisendoerfer, P. and Ziegler, R. (1992), "Survival chances of newly founded business organizations”, American Sociological Review, Vol. 57, pp. 227-242.

Böckerman, P. and Ilmakunnas, P. (2012), "The job satisfaction-productivity nexus: a study using matched survey and register data”, Industrial and Labor Relations Review, Vol. 65 No. 2, pp. 243-262.

Butler, J.E., Brown, B. and Chamornmarn, W. (2003), "Informational networks, entrepreneurial action and performance", Asia Pacific Journal of Management, Vol. 20 No. 2, pp. 151-174.

Camillo, A.A., Connolly, D.J. and Kim, W.G. (2008), "Success and failure in Northern California critical success factors for independent restaurants", Cornell Hospitality Quarterly, Vol. 49 No. 4, pp. 364-380.

Chandler, G.N. and Hank, S.H. (1993), "Measuring the performance of emerging businesses: a validation study", Journal of Business Venturing, Vol. 8, pp. 391-408.

Chow, I.H. (2006), “The relationship between entrepreneurial orientation and firm performance in China", Society for Advancement of Management, Vol. 71 No. 3, pp. 11-20.

Chye, L.T., Tat, H.H., Osman, M.H.M. and Rasli, A.M. (2010), "Are managerial competencies a blessing to the performance of innovative SMEs in Malaysia?", International Journal of Economics and Management, Vol. 4 No. 1, pp. 120-136.

Colombo, M.G. and Grilli, L. (2005), "Founders' human capital and the growth of new technology-based firms: a competence-based view", Research Policy, Vol. 34 No. 6, pp. 795-816.

Cooper, A.C. and Gimeno-Gascon, F.J. (1992), "Entrepreneurs, processes of founding and new firm performance", in Sexton, D.L. and Kasarda, J.D. (Eds), The State of the Art of Entrepreneurship, PWS-Kent, Boston, MA, pp. 301-340.

Cooper, A.C., Gimeno-Gascón, F.J. and Woo, C.Y. (1997), "Initial human and financial capital as predictors of new venture performance", The Journal of Private Equity, Vol. 1 No. 2, pp. 13-30.

Cooper, R.G. (1979), "The dimensions of industrial new product success and failure", Journal of Marketing, Vol. 43 No. 1, pp. 93-103.

Crouch, C., Finegold, D. and Sako, M. (1999), Are Skills the Answer?, Oxford University Press, Oxford. 
EJTD

38,3

176
Dahl, M. and Reichstein, T. (2007), "Are you experienced? Prior experience and the survival of new organizations", Industry and Innovation, Vol. 14 No. 5, pp. 497-511.

Dimov, D.P. and Shepherd, D.A. (2005), "Human capital theory and venture capital firms: exploring 'home runs' and 'strike outs", Journal of Business Venturing, Vol. 20 No. 1, pp. 1-21.

Enz, C.A. (2004), "Issues of concern for restaurant owners and managers", Cornell Hotel and Restaurant Administration Quarterly, Vol. 45 No. 4, pp. 315-332.

Fleetwood, S. and Hesketh, A. (2008), "Theorising under-theorisation in research on the HRM-performance link", Personnel Review, Vol. 37 No. 2, pp. 126-144.

Georgellis, Y., Sessions, J.G. and Tsitsianis, N. (2007), "Pecuniary and non-pecuniary aspects of self-employment survival", Quarterly Review of Economics and Finance, Vol. 47 No. 1, pp. 94-112.

Guest, D.E., Michie, J., Conway, N. and Sheehan, M. (2003), "Human resource management and corporate performance in the UK", British Journal of Industrial Relations, Vol. 41 No. 2, pp. 291-314.

Haber, S. and Reichel, A. (2007), "The cumulative nature of the entrepreneurial process: the contribution of human capital, planning and environment resources to small venture performance", Journal of Business Venturing, Vol. 22 No. 1, pp. 119-145.

Haber, S. and Reichel, A. (2005), "Identifying performance measures of small ventures - the case of the tourism industry", Journal of Small Business Management, Vol. 43 No. 3, pp. 257-286.

Hesketh, A. and Fleetwood, S. (2006), "Beyond measuring the human resources management organizational performance link: applying critical realist meta-theory", Organization, Vol. 13 No. 5, pp. 677-699.

Hitt, M., Bierman, L., Shimizu, K. and Kochhar, R. (2001), "Direct and moderating effects of human capital on strategy and performance in professional service firms: a resource-based perspective", Academy of Management Journal, Vol. 44 No. 1, pp. 13-28.

Jo, H. and Lee, J. (1996), "The relationship between an entrepreneur's background and performance in a new venture", Technovation, Vol. 16 No. 4, pp. 161-171.

Klein, J., Alisultanov, I. and Blair, A. (2003), Microenterprise as a Welfare to Work Strategy: Two-year Findings, The Aspen Institute, Washington, DC.

Kock, H. and Ellström, P.E. (2011), "Formal and integrated strategies for competence development in SMEs", Journal of European Industrial Training, Vol. 35 No. 1, pp. 71-88.

Kock, H., Gill, A. and Ellström, P.E. (2006), "Strategies for competence development at the workplace: learning environments and learning outcomes", conference paper presented at The European Conference on Educational Research ECER.

Lans, T., Wesselink, R., Biemans, H.J.A. and Mulder, M. (2004), "Work-related lifelong learning for entrepreneurs in the agri-food sector", International Journal of Training and Development, Vol. 8 No. 1, pp. 73-89.

Lans, T., Hulsink, W., Baert, H. and Mulder, M. (2008a), "Entrepreneurship education and training in a small business context: insights from the competence-based approach", Journal of Enterprising Culture, Vol. 16 No. 4, pp. 363-383.

Lans, T., Biemans, H., Verstegen, J. and Mulder, M. (2008b), "The influence of the work environment on entrepreneurial learning of small-business owners", Management Learning, Vol. 39 No. 5, pp. 597-613.

Lans, T., Biemans, H., Mulder, M. and Verstegen, J. (2010), "Self-awareness of mastery and improvability of entrepreneurial competence in small businesses in the agrifood sector", Human Resource Development Quarterly, Vol. 21 No. 2, pp. 147-167. 
Lerner, M. and Haber, S. (2001), "Performance factors of small tourism ventures: the interface of tourism, entrepreneurship and the environment", Journal of Business Venturing, Vol. 16 No. 1, pp. 77-100.

McDougall, P.P., Robinson, R.B. Jr and DeNisi, A.S. (1992), "Modeling new venture performance: An analysis of new venture strategy, industry structure, and venture origin”, Journal of Business Venturing, Vol. 7 No. 4, pp. 267-289.

Mabey, C. (2008), "Management development and firm performance in Germany, Norway, Spain and the UK", Journal of International Business Studies, Vol. 39 No. 8, pp. 1327-1342.

Mabey, C. and Gooderham, P. (2005), "The impact of management development on perceptions of organizational performance in European firms", European Management Review, Vol. 2 No. 2, pp. 131-142.

Mabey, C. and Ramirez, M. (2005), "Does management development improve organizational productivity? A six-country analysis of European firms", International Journal of Human Resource Management, Vol. 16 No. 7, pp. 1067-1082.

Man, T.W.Y., Lau, T. and Snape, E. (2008), "Entrepreneurial competencies and the performance of small and medium enterprises: an investigation through a framework of competitiveness", Journal of Small Business and Entrepreneurship, Vol. 21 No. 3, pp. 257-276.

Man, T.W.Y., Lau, T. and Chan, K.F. (2002), "The competitiveness of small and medium enterprises: a conceptualization with focus on entrepreneurial competencies", Journal of Business Venturing, Vol. 17 No. 2, pp. 123-142.

Maroto, A. and Rubalcaba, L. (2008), "Services productivity revisited”, Service Industries Journal, Vol. 28 No. 3, pp. 337-353.

Martin, G. and Staines, H. (1994), "Managerial competences in small firms", Journal of Management Development, Vol. 13 No. 7, pp. 23-34.

Mengistae, T. (2006), “Competition and entrepreneurs' human capital in small business longevity and growth", The Journal of Development Studies, Vol. 42 No. 5, pp. 812-836.

Millan, J.M., Congregado, E. and Roman, C. (2012), "Determinants of self-employment survival in Europe”, Small Business Economics, Vol. 38 No. 2, pp. 231-258.

Mohr, J. and Spekman, R. (1994), "Characteristics of partnership success: partnership attributes, communication behavior and conflict resolution techniques", Strategic Management Journal, Vol. 15 No. 2, pp. 135-152.

Mulder, M., Lans, T., Verstegen, J., Biemans, H. and Meijer, Y. (2007), "Competence development of entrepreneurs in innovative horticulture”, Journal of Workplace Learning, Vol. 19 No. 1, pp. 32-44.

Murphy, G.B., Trailer, J.W. and Hill, R.C. (1996), "Measuring performance in entrepreneurship research", Journal of Business Research, Vol. 36 No. 1, pp. 15-23.

Mwasalwiba, E.S. (2010), "Entrepreneurship education: a review of its objectives, teaching methods, and impact indicators", Education + Training, Vol. 52 No. 1, pp. 20-47.

O'Connor, A. (2013), "A conceptual framework for entrepreneurship education policy: meeting government and economic purposes", Journal of Business Venturing, Vol. 28 No. 4, pp. 546-563.

O'Gorman, C. (2001), "The sustainability of growth in small- and medium-sized enterprises", International Journal of Entrepreneurial Behaviour and Research, Vol. 7 No. 2, pp. 60-75.

Orser, B.J., Hogarth-Scott, S. and Riding, A.L. (2000), "Performance, firm size and management problem solving”, Journal of Small Business Management, Vol. 38 No. 4, pp. $42-58$. 
EJTD

38,3

\section{8}

Panagiotakopoulos, A. (2011), "What drives training in industrial micro-firms? Evidence from Greece", Industrial and Commercial Training, Vol. 43 No. 2, pp. 113-120.

Parker, S.C. and van Praag, C.M. (2006), "Schooling, capital constraints, and entrepreneurial performance: the endogenous triangle", Journal of Business and Economic Statistics, Vol. 24 No. 4, pp. 416-431.

Purcell, J. and Hutchinson, S. (2007), "Front-line managers as agents in the HRM performance causal chain: theory, analysis and evidence", Human Resource Management Journal, Vol. 17 No. 1, pp. 3-20.

Rainbird, H. (2000), "Training in the workplace and workplace learning: introduction", in Rainbird, H. (Ed.), Training in the Workplace, Macmillan Press, Basingstoke.

Reynolds, P.D. (2012), "Entrepreneurship in developing economies: the bottom billions and business creation", Foundations and Trends in Entrepreneurship, Vol. 8 No. 3, available at: SSRN: http://ssrn.com/abstract=2137727.

Sanders, C. (2002), "The impact of micro enterprise assistance programs: a comparative study of program participants, non-participants, and other low-wage workers", Sociological Service Review, Vol. 76 No. 2, pp. 321-342.

Schön, L. (2010), Sweden's Road to Modernity: An Economic History, SNS Förlag, Stockholm.

Segal, G., Borgia, D. and Schoenfeld, J. (2007), "Founder education and experience as predictors of small firm performance", pp. 63-67, in proceedings from Allied Academies International Conference, Vol. 13 No. 1, Jacksonville, April 11-14, Florida, Academy of Entrepreneurship.

Segal, G., Borgia, D. and Schoenfeld, J. (2010), "Founder human capital and small firm performance: an empirical study of founder-managed natural food stores", Journal of Management and Marketing Research, Vol. 4 No. 1, pp. 71-83.

Seghers, A., Manigart, S. and Vanacker, T. (2012), "The impact of human and social capital on entrepreneurs' knowledge of finance alternatives”, Journal of Small Business Management, Vol. 50 No. 1, pp. 63-86.

Sharlit, I. (1990), "Six early warning signs of business failure", Executive Psychology, March, pp. 26-30.

Soriano, D.R. and Castrogiovanni, G.J. (2012), "The impact of education, experience and inner circle advisors on SME performance: insights from a study of public development centers", Small Business Economics, Vol. 38 No. 3, pp. 333-349.

Sapienza, H.J. and Grimm, C.M. (1997), "Founder characteristics, start-up processes, and strategy/structure variables as predictors of shortline railroad performance", Entrepreneurship Theory and Practice, Vol. 22 No. 1, pp. 5-24.

Spalter-Roth, R., Soto, E., Zandniapour, L. and Braunstein, J. (1994), Micro-enterprise and Women: The Viability of Self-employment as a Strategy for Alleviating Poverty, Institute for Women's Policy and Research, Washington, DC.

Steiner, M.P. and Solem, O. (1988), "Factors for success in small manufacturing firms", Journal of Small Business Management, Vol. 26 No. 1, pp. 51-56.

Tsai, W.M., McMillan, I.C. and Low, M.B. (1991), "Effects of strategy and environment on corporate venture success in industrial markets", Journal of Business Venturing, Vol. 6 No. 1, pp. 9-28.

Zellner, A. and Theil, H. (1962), "Three-stage least squares: simultaneous estimation of simultaneous equations", Econometrica: Journal of the Econometric Society, Vol. 30 No. 1, pp. 54-78. 


\section{Further reading}

Chandler, G.N. and Jansen, E.J. (1992), "Founder's self-assessed competence and venture performance", Journal of Business Venturing, Vol. 7 No. 3, pp. 223-236.

Hussain, J., Matlay, H. and Scott, J.M. (2008), "Financial education in small ethnic minority businesses in the UK", Education + Training, Vol. 50 Nos 8/9, pp. 737-747.

\section{Corresponding author}

Dr Saeid Abbasian can be contacted at: saeid.abbasian@miun.se 